\title{
Effects of reindeer grazing and recovery after cessation of grazing on the ground-dwelling spider assemblage in Finnish Lapland
}

\author{
Teemu Saikkonen $^{1}$, Varpu Vahtera ${ }^{1}{ }^{,}$, Seppo Koponen ${ }^{1}$, Otso Suominen $^{\text {Corresp. }}{ }^{2}$ \\ ${ }^{1}$ Zoological Museum, Biodiversity Unit, University of Turku, Turku, Finland \\ 2 Kevo Subarctic Research Institute, Biodiversity Unit, University of Turku, Turku, Finland \\ Corresponding Author: Otso Suominen \\ Email address: otsosuo@utu.fi
}

The effect of reindeer Rangifer tarandus L. grazing on the ground-dwelling spider assemblage in Northern Finland was studied. Changes in species richness, abundance and evenness of spider assemblages were analyzed in relation to changes in vegetation and environmental factors in long term grazed and ungrazed sites as well as sites that had recently switched from grazed to ungrazed and vice versa. Grazing was found to have a significant impact on height and biomass of lichens and other ground vegetation. However, it seemed not to have an impact on the total abundance of spiders. This is likely caused by opposing family and species level responses of spiders to the grazing regime. Lycosid numbers were highest in grazed and linyphiid numbers in ungrazed areas. Lycosidae species richness was highest in ungrazed areas whereas Linyphiidae richness showed no response to grazing. Four Linyphiidae, one Thomisidae and one Lycosidae species showed strong preference for specific treatments. Sites that had recovered from grazing for nine years and the sites that were grazed for the last nine years but were previously ungrazed resembled the long term grazed sites. The results emphasize the importance of reindeer as a modifier of boreal forest ecosystems but the impact of reindeer grazing on spiders seems to be family and species specific. The sites with reversed grazing treatment demonstrate that recovery from strong grazing pressure at these high latitudes is a slow process whereas reindeer can rapidly change the conditions in previously ungrazed sites similar to long term heavily grazed conditions. 
1 Effects of reindeer grazing and recovery after cessation of grazing on the ground-dwelling 2 spider assemblage in Finnish Lapland

3

4 Teemu Saikkonen ${ }^{1}$, Varpu Vahtera ${ }^{1}$, Seppo Koponen ${ }^{1} \&$ Otso Suominen ${ }^{2 *}$

5

6 'Zoological Museum, Biodiversity Unit, University of Turku, Turku, Finland

$7 \quad{ }^{2}$ Kevo Subarctic Research Institute, Biodiversity Unit, University of Turku, Turku, Finland

8

9

$10 *$ Corresponding author:

11 Otso Suominen ${ }^{2}$

12 E-mail address: otsosuo@utu.fi

13 


\section{Abstract}

15 The effect of reindeer Rangifer tarandus L. grazing on the ground-dwelling spider assemblage in

16 Northern Finland was studied. Changes in species richness, abundance and evenness of spider

17 assemblages were analyzed in relation to changes in vegetation and environmental factors in

18 long term grazed and ungrazed sites as well as sites that had recently switched from grazed to

19 ungrazed and vice versa. Grazing was found to have a significant impact on height and biomass

20 of lichens and other ground vegetation. However, it seemed not to have an impact on the total

21 abundance of spiders. This is likely caused by opposing family and species level responses of

22 spiders to the grazing regime. Lycosid numbers were highest in grazed and linyphiid numbers in

23 ungrazed areas. Lycosidae species richness was highest in ungrazed areas whereas Linyphiidae

24 richness showed no response to grazing. Four Linyphiidae, one Thomisidae and one Lycosidae

25 species showed strong preference for specific treatments. Sites that had recovered from grazing

26 for nine years and the sites that were grazed for the last nine years but were previously ungrazed

27 resembled the long term grazed sites. The results emphasize the importance of reindeer as a

28 modifier of boreal forest ecosystems but the impact of reindeer grazing on spiders seems to be

29 family and species specific. The sites with reversed grazing treatment demonstrate that recovery

30 from strong grazing pressure at these high latitudes is a slow process whereas reindeer can

31 rapidly change the conditions in previously ungrazed sites similar to long term heavily grazed

32 conditions. 


\section{Introduction}

Wild reindeer have been a natural part of the northern boreal ecosystems in Eurasia since the last ice age, but in northern Fennoscandia and many parts of northern Russia they have been replaced by reindeer husbandry with a sustained high density of semi-domesticated reindeer. Contrary to the reindeer herding practices in Norway and Sweden, in Finland, semi-domesticated reindeer herds can no longer have the traditional long migration between their separate summer and winter ranges. The Finnish reindeer herding area is divided into 57 herding districts defined by legislation (Suominen \& Olofsson 2000). These districts are relatively small (about 1000 to $5000 \mathrm{~km}^{2}$ ) compared to the herding areas in Norway and Sweden and prevent long term migration. At present, modern herding practices force reindeer herds in Finland to graze in restricted areas. It is especially detrimental to the lichen dominated winter pastures, if reindeer are forced to use them at summertime since that leads to strong trampling impact. Kumpula et al. 2000 showed that the condition of lichen rich winter pastures is not explained by reindeer density in relation to the total land area of a herding district but by the density of reindeer in relation to

51 the area of lichen ranges. Nowadays with the inclusion of supplementary feeding which prevents natural mortality owing to shortage of food, the grazing pressure in relation to the carrying capacity of pastures can rise excessively high (Kojola et al. 1991, Helle \& Kojola 1993; Evans 1996; Kumpula et al. 1997; Suominen \& Olofsson 2000). Local herders' cooperatives are trying to save their best winter grazing areas from overgrazing by a system of pasture rotation system (Kumpula et al. 1999), but the success of this is limited. In the boreal ecosystem, the semi-domesticated reindeer (Rangifer tarandus tarandus L.) 
59 engineer concept (Jones et al. 1994; 1997) implies that, in addition to impacts of reindeer

60 through trophic interactions, they control the physical properties of the ecosystem as well. The

61 concept of disturbance, according to the intermediate disturbance hypothesis (IDH) (Connel

62 1978), implies that the species diversity is at its peak when the level of disturbance is

63 intermediate. IDH has often been applied to the impact of herbivores on vegetation diversity.

64 Both roles stem from grazing behavior and are not mutually exclusive.

Sustained high density of deer has been shown to have a negative impact on vegetation and this impact is further cascades to the whole ecosystem including animal assemblages (Côté et al. 2004). Several studies have demonstrated that the changes caused by large herbivores can have an impact on species composition and abundance of several other animal taxa through various direct and indirect mechanisms (reviewed in Suominen \& Danell 2006 and Foster et al. 2014). At the current constantly high densities reindeer herds have substantial influence on the environment; irrespective of whether reindeer considered to be a native part of the ecosystem or a disturbance due to high densities and lack of natural pasture rotation migration. For instance, grazing can change, sustain and create habitats (Putman 1994), accelerate (Kielland et al. 1997; Augustine \& McNaughton 1998; Stark et al. 2000; 2002; Olofsson et al. 2004) and even decelerate nutrient flux by affecting the detritus food web via changes in microclimate (Väre et al. 1996; Pastor \& Cohen 1997; Augustine \& McNaughton 1998; Olofsson et al. 2001). In addition, grazing has an impact on the community structure and species diversity of vegetation (e.g. Väre et al. 1996; Pastor \& Naiman 1992; Pastor \& Cohen 1997; Milchunas et al. 1998; Suominen 1999) and can influence the post-disturbance succession rate of vegetation (Oksanen et al. 1995; Kielland et al. 1997; Helle et al. 1998). The impacts of reindeer on vegetation and soil properties as well as on the interaction between soils, vegetation and climate change have 
82 been studied a lot in recent years (e.g. Eskelinen et al. 2017; Kaarlejärvi et al. 2017; Ylänne et

83 al. 2017; Egelkraut et al. 2018; Maliniemi et al. 2018). Especially in winter ranges of reindeer in

84 boreal forests, which are typically dry pine forests with Cladonia-lichen dominated bottom layer

85 vegetation, it has been shown that the main impact of reindeer is a strong sift from thick lichen

86 carpets to much less bottom and field layer vegetation (e.g. Väre et al. 1996, Suominen \&

87 Olofsson 2000, Köster et al. 2013). In addition to biomass and composition of forest floor

88 vegetation this then has cascading impacts on other ecosystem properties such as tree

89 recruitment, fungal communities, litter decomposition (Köster et al. 2013, 2015, Santalahti et al.

90 2018). Variation observed in vegetation can subsequently mediate the impact of grazing on

91 invertebrate partners in a community (Owen-Smith 1987; DeCalesta 1994; Baines et al. 1994;

92 Bromham et al. 1999; Suominen 1999; Wardle et al. 2001; Suominen et al. 2003; Suominen \&

93 Danell 2006; Foster et al. 2014).

94 The forest floor spider community is greatly influenced by the habitat's abiotic

95 conditions, such as moisture, light and temperature (Uetz 1991) as well as by the structure of the

96 vegetation and other three dimensional habitat microhabitat features (Colebourn 1974, Hatley \&

97 Macmahon 1980, Koponen 1995), and the presence of reindeer can change these conditions and

98 these changes can have an impact on the availability of prey for spiders. Since spiders act both as

99 abundant predators in the invertebrate community and as important prey for numerous forest

100 animals, the changes in spider assemblage can further cascade through the food web via

101 numerous direct and indirect ways.

102 In this study, we show the impact of reindeer grazing and trampling on the ground-

103 dwelling spider fauna in a special area with four different types of reindeer grazing history. It is

104 also unique in the way that moose (Alces alces) is present in both sites with and without reindeer 
105 grazing. Our hypothesis is that reindeer through the changes caused in vegetation height,

106 structure and biomass as well as in the abiotic conditions has an impact on the assembly structure

107 of spiders. More specifically, we hypothesize that sites with recently reversed reindeer grazing

108 status would have intermediate environmental conditions and assembly structure compared long

109 term grazed and ungrazed sites. Following the IDH assumptions we expected a peak in diversity

110 of spider assemblages at intermediate grazing treatments compared to long term grazed or

111 ungrazed pastures.

\section{Study area and methods}

116 The study area (Fig. 1) was in eastern Finnish Lapland, in Raja-Jooseppi Inari $\left(68^{\circ} 28^{\prime} \mathrm{N}, 28^{\circ}\right.$

117 28'E) where semi-domesticated reindeer have been traditionally herded by tradition by Sámi

118 people for centuries on the Finnish territory. The study site was in dry lichen dominated pine

119 heath of typical reindeer winter pasture on Lappi reindeer herding district's eastern boarder. The

120 district has got an area of $4396 \mathrm{~km}^{2}$, and its maximum number of overwintering reindeer is 8000

121 individuals. On the Russian side of the national border there are no wild or semi-domesticated

122 reindeer in the area close to the border. The study sites were in the restricted border zone on the

123 Finnish side of the border. We had a permission for the work from the Finnish Boarder Guard

124 (permit number 2717/2015).

125 A reindeer fence along the Finnish-Russian border was erected in the 1940s, and in 1997

126 a new fence crossing the old one was built in our study area. With time, the old fence was torn

127 down so that herds could enter untouched pastures. The junction of the new fence and the 
128 position of the old fence forms a cross, where four different grazing regions are distinctly

129 present: i) UGraz - continuously ungrazed from 1940. ii) Graz - continuously grazed from at

130 least 1940. iii) (new ungrazed) NUGraz - ungrazed from 1997, but previously grazed. iiii) (new

131 grazed) NGraz - grazed from 1997 but previously ungrazed.

132 Reindeer fences prevent reindeer from entering the Russian side, where reindeer are

133 locally extinct due to historical causes. Moose, however, occur on both sides and are capable of

134 crossing the fences. This gives a unique opportunity to solely study the grazing effects of

135 reindeer.

136

137

138 Pitfall trapping

139

140 Spiders were collected using pitfall traps. The traps were plastic cups $170 \mathrm{ml}$ in volume each

141 with a mouth diameter of $70 \mathrm{~mm}$. The killing / preserving fluid was a mix of polypropylene

142 glycol (60\%) and tap water, with a hint of detergent added. With pitfall traps it is possible to

143 passively collect a large proportion of actively moving fauna, and being abundant and actively

144 moving creatures, spiders are frequently encountered in pitfalls. A comparison of spider

145 sampling techniques has proved pitfall trapping to maintain its catching efficiency most

146 constantly in time (Churchill \& Arthur 1999).

147

148 Trapping design

149 
150 A total of 36 trap lines, each consisting of five traps positioned three meters apart, were placed in

151 six plots in the vicinity of the reindeer fence junction in an area of $150 \times 500$ meters. Each plot

152 included three treatments: the upper region of the fence crossing had Graz, NGraz and UGraz;

153 the lower region had Graz, NUGraz and UGraz. Each treatment within a plot had two trap lines

154 had two trap lines, one five meters from the fence and another 20 meters from the fence. All the

155 trap lines were parallel to the fence. Duo to the possible fence effect, i.e. packing of the deer

156 against the fence and thus higher grazing and trampling impact (e.g. Oksanen 1978, Olsofsson et

157 al. 2001), we tested prior to the further analyses whether the lines with different distance to the

158 fence differed from each other (paired t-test or Wilcoxon signed-ranks test ).

159 The trapping period was two months from early June to early August 2005 and due to the

160 short summer of northern boreal regions it practically covered the entire growing season. The

161 emptying interval was one month.

162 Identification of mature specimens was done to species level. As juveniles often lack

163 distinctive species characters (Norris 1999) they were identified to family level.

Vegetation and environmental factors

Species composition and height of field and bottom layer vegetation was evaluated with a $50 \mathrm{x}$

$16850 \mathrm{~cm}$ square situated in the middle of each trap line. Dry biomass of the vegetation and soil

169 moisture of soil samples were collected in mid-July, and measured in the laboratory. In each trap

170 line, temperature was measured at the depth of $5 \mathrm{~cm}$ in the soil (June $7^{\text {th }} 2005$, to nearest $0.1{ }^{\circ} \mathrm{C}$ ).

171 Since the impacts of reindeer on Cladina lichen dominated forest floor vegetation have been

172 documented in several other studies (e.g. reviews by Suominen \& Olofsson 2000, Bernes et al.

173 2015), and the main focus of the present study is on the spider community, we present the 
174 vegetation results here only as major functional groups pooled over species: lichens, mosses and

175 vascular plants. In our study sites, all other vascular plants than ericaceous dwarf shrubs, were

176 too rare to be statistically tested, and all these shrubs had similar response to treatments. Thus,

177 the result on vascular plants is in fact equal to the response of these shrubs.

178

\section{Data analysis}

180

Data was analyzed using SAS Enterprise Guide 3.0, EcoSim (Gotelli \& Entsminger 2001), and

182 Canoco for Windows 4.5 (ter Braak \& Smilauer 1998). Equality of variances was tested with

183 Levene's test. Normality of residuals was tested with the Shapiro-Wilk test. Variables that were

184 not normally distributed were analyzed with the nonparametric Kruskal-Wallis $\chi^{2}$-test or

185 Spearman rank correlation (see the table captions). Since many key variables such as spider

186 abundances and plant biomasses could not be analysed with parametric tests the effect of

187 treatments on even those response variables that fulfilled the requirements of parametric tests

188 were also tested with simple one-way ANOVA. In the statistical analyses we used trapping lines

189 as sampling units (observations) i.e. data over the individual traps on each line was combined.

190 The vegetation and physical variables were also measured at trapping line level.

191 Interactions between environmental variables and species were analyzed using linear

192 regression. The Detrended Correspondence Analysis (DCA) ordination method was used to

193 analyze community structure. The two options "downweighting of rare species" and "trend

194 correction by segments" of Canoco for Windows were turned on.

195 As the number of species and the number of individuals per sample are often strongly

196 correlated, the number of individuals caught in each trap line was adjusted by rarefaction (see

197 Gotelli \& Colwell 2001) to make trap lines of dissimilar catch size comparable. 


\section{Results}

201

202

The distance of the trap line from the fence, i.e. "fence effect", was found to have no effect on spiders and vegetation (paired t-test or Wilcoxon signed-ranks test, $\mathrm{p}>0.1$ ) and in the subsequent analysis this classifying factor was removed.

\section{General abundance and species numbers}

207

A total of 4225 spider specimens were collected during the whole sampling period. Of these, 3426 specimens were collected from early June till early July and 804 from early July to early August. Mature spiders that were identified to species level numbered 3241 individuals, and 984

211 specimens were juveniles and therefore identified to family level only (see Supplement for a 212 complete list of specimens). In total 73 spider species were caught, representing 11 families 213 (Table 1).

214 In terms of specimen numbers (number of spider individuals, abundance), the most

215 common families were wolf spiders (Lycosidae) and sheet weavers (Linyphiidae). Nearly one

216 third of the mature spiders were wolf spider Pardosa eiseni or Alopecosa aculeata individuals.

217 The twelve most common species comprised $76 \%$ of the total number of spiders (Table 2). Eight 218 species were encountered only once. 
222 Total lichen dry biomass (Fig. 2) and lichen height differed significantly between treatments

$223\left(\mathrm{df}=5, \chi^{2}=26,65, p<0.0001 ; \mathrm{df}=5, \chi^{2}=43,18, p<0.0001\right)$ Soil moisture did not differ between

224 treatments, but soil temperature $\operatorname{did}(\mathrm{df}=5, \mathrm{~F}=4.09 p=0.0212)$ (Fig. 2). The impact of treatment

225 on response variables is shown in Table 3.

226 Dry biomasses of mosses or vascular plants were not significantly affected by grazing

227 (Table 3). Vegetation height differed significantly between treatments for all functional groups

228 i.e. lichens, mosses, and dwarf shrubs (practically all vascular plants in the field layer were dwarf

229 shrubs) all being highest in ungrazed plots (Table 3).

230 Most common vascular plants were dwarf shrubs ling (Calluna vulgaris), lingonberry

231 (Vaccinium vitis-idaea), crowberry (Empetrum nigrum) and bilberry (V. myrtillus). In addition

232 to those, some graminoids (Poaceae), willow (Salix spp.), bog bilberry (Vaccinium uliginosum)

233 and marsh Labrador tea (Rhododendron tomentosum, ex. Ledum palustre) grew on some sites.

234 Among these plants there were three, which typically characterize more moist or even marshy

235 sites, that were found only or almost exclusively in the long term ungrazed sites. Bog bilberry

236 and Sphagnum-mosses were found only in the ungrazed sites where their occurrence frequencies

237 were $36 \%$ and $20 \%$ of the studied plots. For marsh Labrador tea the occurrence frequency was

$23864 \%$ in ungrazed and $18 \%$ in grazed sites.

239 Soil moisture and soil temperature $(\mathrm{df}=16, \mathrm{~F}=8.18, p=0.011)$, and lichen biomass and

240 soil temperature $(\mathrm{df}=16, \mathrm{~F}=8.93, p=0.009)$ correlated negatively, whereas no correlation was

241 found between soil moisture and lichen biomass (Figs 3 a-c).

\section{Impacts of grazing on spiders}




\section{Abundance}

245

246 The total number of all spider individuals was similar between treatments, but at the family level

247 there were differences (Table 3), correlations between spider families are shown in Table 4).

248 Wolf spiders (Lycosidae) were most numerous in long grazed and recently grazed treatments;

249 sheet weavers (Linyphiidae) were most abundant in ungrazed areas, while crab spiders

250 (Thomisidae) showed a more complex yet family specific pattern (Table 3, Fig. 4).

251 Sheet weavers Palliduphantes antroniensis and Hilaira herniosa clearly occurred most

252 often in ungrazed areas, whereas the sheet weaver Agyneta gulosa and the crab spider Ozyptila 253 arctica were as clearly restricted to grazed areas (Fig. 5).

\section{Species richness}

257

258

Rarefied trap line species richness ( $\mathrm{n}=123$ for each trap line) did not differ significantly between treatments (Table 3). The rarefied wolf spider species richness $(n=21)$ was affected by treatments. The highest number of species (6, SD 0.4) was detected in ungrazed sites, the lowest in sites with a long history of grazing (3.5, SD 0.2).

264 showed no response to grazing. 


\section{Impact of vegetation and environmental factors on spiders}

269

270 With increasing Cladina dry mass and height, the abundance of linyphiids and species richness

271 of lycosids increased but the abundance of thomisids decreased (Table 5). Biomass of vascular

272 plants did not correlate with the abundance or richness of any of the tested spider taxa (Spearman

273 correlation $\mathrm{n}=36, \mathrm{r}<0.27, \mathrm{P}>0.11$ ). Moss biomass correlated negatively with Lycosidae richness

274 (Spearman correlation $\mathrm{n}=36, \mathrm{r}=-0.460, \mathrm{P}=0.005$ ), but not with other spider variables.

275 Of the most common species Ozyptila arctica (Thomisidae) and Agyneta gulosa

276 (Linyphiidae) decreased in abundance with increasing lichen dry mass and height, whereas

277 Palliduphantes antroniensis (Linyphiidae) was clearly more abundant in areas with thick lichen

278 cover. Also, Hilaira herniosa (Linyphiidae) showed a similar pattern to P. antroniensis. Other

279 common species showed no response to changes in lichen dry mass or height (Table 5). With

280 increasing soil moisture, the abundance of Gnaphosidae and the total species richness of spiders

281 increased significantly. Micrargus herbigradus and Pocadicnemis pumila (Linyphiidae) were

282 more abundant in moister areas, whereas A. gulosa numbers decreased with increasing moisture.

283 The other common species did not respond significantly to soil moisture.

284 Higher soil temperature was connected to a decrease in linyphiid abundance, rarefied

285 lycosid species richness and the total rarefied species richness of the spider assemblage in each

286 treatment (Table 5). M. herbigradus and P. antroniensis decreased in abundance, while A. gulosa

287 abundance was significantly higher in sites with warmer soil.

288

289

Correlations between spider families

290 
291 Correlations between abundances and species richnesses of spider the two most numerous spider

292 families, Lycosidae and Linyphiidae, are shown in Table 4. For the overall spider abundance and

293 richness we used the abundance and richness of all other spider families than the one that was

294 tested for, i.e. for Lycosidae all spiders except lycosids and for Linyphiidae all other spiders than

295 linyphids. The abundance of wolf spider individuals correlates negatively with their own

296 rarefied species richness and positively with the abundance of other spiders and the richness of

297 linyphid spiders. The species richness of Lycosidae spiders correlated positively with the

298 abundance of Linyphiidae and negatively with the richness other spiders and especially that of

299 linyphids. High species richness of linyphids was associated with high abundance of spiders of

300 other families. Earlier, Marusik \& Koponen (2002) have found that rich lycosid fauna correlates

301 with high overall species richness in the spider community as well analogous patterns. In our

302 case the opposite was found when the lycosids themselves were excluded from the overall spied

303 richness.

304

305

\section{Multidimensional scaling}

306

307 A DCA-ordination visualizing the effect of environmental factors and treatments on spider

308 communities is presented in Fig 6. Treatments are distinctly located on different sides of the

309 graph depending on grazing history. Recently grazed and recently ungrazed treatments are

310 grouped with long grazed areas on the first ordination axis, leaving the ungrazed area at the other

311 end of the gradient. On the second ordination axis, no clear differences are detectable, except a

312 more narrow distribution of ungrazed areas. Soil temperature and soil moisture varies between

313 trap lines fairly independently of lichen dry biomass, but covary with each other to some extent. 
315 mainly represents lichen biomass as in Fig. 6. Agyneta conigera and A. gulosa (Linyphiidae) are

316 clearly detached from other species, indicating a preference for grazed areas over ungrazed. The

317 lichen rich end of the first axis is dominated by H. herniosa (Linyphiidae), Robertus lividus

318 (Theridiidae) and especially P. antroniensis (Linyphiidae).

319 On the second axis Pardosa hyperborea (Lycosidae) represents a distinct end point. $H$.

320 herniosa and Minyriolus pusillus (Linyphiidae) amongst others are found the opposite end.

321 Xysticus obscurus (Thomisidae) is a species that did not react to the first axis, but reacted

322 strongly to the second, while other species were situated somewhere between.

323

324 Discussion

325

\section{Impact of grazing on spiders}

327

328

Both family and species level responses to grazing were extensive in lycosids and linyphids, 329 even though the combined abundance or species richness of all spiders did not differ between treatments.

As expected, wolf spiders were more abundant in grazed areas, and the response of sheet weavers was entirely the opposite. Several explanations for this pattern can be found. Wolf spiders chase their prey at ground level, thus making open habitat the optimal foraging ground.

334 Wolf spiders are also relatively large in body size, making it hard to exploit thick, porous lichen

335 carpet as a hunting ground. Also, because this group hunts actively by running, warmer and drier 336 ground may be more suitable for them. Lower numbers of lycosids in ungrazed areas can also be 
337 explained by a lower number of suitable prey (Suominen 1999), in addition to physically more

338 demanding substrate. Linyphiidae spiders catch their prey by using webs, thus their habitat

339 should comprise suitable anchoring sites for web structures. The abundance of web-building

340 spiders has been found to be limited by both the availability of suitable web sites and prey

341 availability (Minoshima et al. 2013, and references therein). Grazing has been shown to decrease

342 both abundance and species richness of web-hunting spiders in Japan and in Kenya, by removing

343 suitable web-building sites (e.g. Miyashita et al. 2004; Warui et al. 2005; Takada et al. 2008;

344 Minoshima et al. 2013). Some studies have suggested that the impact of large herbivores could

345 also be mediated through the abundance of prey (Suominen et al. 2008; Takada et al. 2008) or

346 direct physical disturbance to the spider webs (Foster et al. 2015). In several of these studies the

347 method obtaining spider counts in the field has been based on direct observations of spider webs.

348 This partially circularly reasoning methodology might overemphasize the importance of web

349 building structures for the abundance of web-building spiders. Sweep net sampling in an area

350 close to the present study site during the same summer did not show significant differences in the

351 amount of insect prey (see supplementary material). Since the study area is typical winter pasture

352 for reindeer it is unlikely that there would be substantial direct disturbance of the webs by

353 reindeer during summer. A lack of suitable construction sites for webs and possibly also the

354 different microclimate conditions (i.e. humidity and temperature) seem feasible explanations in 355 this study.

356 Thomisidae abundance in both intermediate treatments strongly reflected the grazing

357 history of the intermediate treatments. The observed similarity between recently ungrazed and

358 continuously grazed sites could be explained by the slow recovery of vegetation. However, as 
359 continuously ungrazed and recently grazed sites also showed a resemblance, this hypothesis of

360 prolonged succession seems incorrect.

361

362 Species richness of spiders

363

364 The response of rarefied wolf spider species richness to treatments was as expected. In the

365 presumably favourable sites species richness was low and abundance high, whereas in low

366 quality sites species richness was high and abundance low. This is well in line with the

367 competitive exclusion theory, according to which strong competitors in good quality habitats can

368 outcompete subdominants with a similar ecological niche, hence leading to lower species

369 richness (Gause 1934; Hardin 1960). In suboptimal, ungrazed habitats, competitive exclusion is

370 not effective as other factors than inter-species competition are more limiting. A high number of

371 species could be seen as a sign of a more heterogeneous habitat, where more species can live

372 together. However, a monotonous thick and dense carpet of lichen is not likely to be more

373 heterogeneous than grazed areas or provide more suitable environments for ground dwelling

374 wolf spiders.

375 Species richness within Linyphiidae family did not differ between treatments. As

376 linyphiids are highly efficient in their dispersal capacities (ballooning method), they can respond

377 efficiently to environmental changes. Yet, due to wind-driven and rather erratic dispersal,

378 linyphiids are also often dispersed to suboptimal habitats, hence the species present in one spot

379 might reflect chance only. Linyphiid abundance, however, can tell more about the actual quality

380 of the habitat. 


\section{Spider species responses}

385 A. gulosa and A. conigera, linyphid species found in grazed areas in high numbers, typically

386 prefer areas in an early successional phase just after disturbance and are even considered pioneer

387 species (Koponen 2004; Koponen \& Koneva 2006). Occurrence of pioneer species in an area

388 grazed continuously from at least the 1940s shows that grazing pressure is high enough to keep

389 an area constantly in its early stage of succession. Linyphiidae spiders. $P$. antroniensis and $H$.

390 herniosa are typical northern boreal bottom layer species (Koponen 1999), and here strictly

391 occurred in great abundance in ungrazed, reindeer-free areas.

392 Of the species that are not web-spinning, Xysticus obscurus (Thomisidae) was restricted

393 to humid areas, but was rather infrequent in abundance and was previously found in multiple

394 habitats (Koponen 1977). P. hyperborea also indicated predominantly lichen rich, humid areas,

395 but was also highly abundant in one site with low lichen biomass. The crab spider $O$. arctica was

396 exceptional in its abundance by being most common in long term grazed sites as well as in newly

397 ungrazed site.

398 Linear regression revealed the affinity of Micrargus herbigradus (Linyphiidae) to cool

399 and moist sites. However, its occurrence was not affected by lichen biomass.

400 DCA-ordination did not group species into families but instead showed greatly differing

401 environmental affinities, even within a genus. Hence, use of higher taxa than species to describe

402 changes in environmental attributes can be misleading if the responses of the species contradict

403 each other and the researcher is not utterly aware of the ecology of the focal species. 


\section{Importance of microclimate for spiders}

In addition to causing differences in lichen biomass and height as well as other direct and

410 indirect impacts on vegetation, grazing induces differences in microclimate, which may also

411 explain the observed patterns in spider fauna (Koponen et al. 1975; Samu et al. 1999; Frick et al.

412 2007). Large, actively moving wolf spiders require a warmer habitat than small, relatively

413 motionless web-hunting spiders. Due to their small body size, linyphiids are also more

414 vulnerable to drying out. Inside and on top of the spongy, absorbent lichen carpet, the risk of

415 desiccation is probably less important. Also, Riechert and Tracy (1975) showed that by building

416 webs in physically optimal sites instead of sites maximizing prey catch, web-building spiders

417 could significantly increase their fitness.

Impact of grazing on vegetation and environmental variables

421 As expected and shown by numerous previous studies (e.g. Väre et al. 1996, Suominen \&

422 Olofsson 2000, Köster et al. 2013), the main impact of reindeer on vegetation was a reduction in

423 reindeer lichens. Reindeer significantly reduced both the biomass and the height of their main

424 winter food, the Cladina lichens, that otherwise dominate ground layer vegetation in these

425 forests. Grazing also raised the soil temperature in summer by removing the isolating and

426 reflecting layer of white thick lichen. This differs from the results of the study by Köster et al.

427 (2015). They didi not find significant difference in soil temeprature in fairly similar conditions

428 not so far away from our study site. We did not detect significant differences in soil moisture 
429 between treatments, and this is similar to the results of Köster et al. (2015). This may have been

430 a result of small-scale topographical differences at the study site. However, occurrence of typical

431 peatland species on the sandy soil of our study area like the spider Pardosa sphagnicola and

432 plants like peat moss (Sphagnum spp.) and bog bilberry in the long term ungrazed area implies

433 that there are actual differences in moisture levels between treatments. Also Pardosa

434 hyperborea, being relatively abundant in our samples in ungrazed areas, is known to prefer moist 435 conditions (Koponen 1977), even to the extent of being one of the dominant species in peatlands 436 of the boreal zone (Koponen 2002).

437 The DCA ordination of the spider community split the treatments along two gradients: a 438 first ordination axis that mainly represented lichen biomass and a second axis representing soil 439 moisture and temperature. The latter, however, could not divide the species as clearly as the first. 440 Most of the long grazed sites, along with intermediate treatments, were located at a relatively dry 441 section of the gradient. The first axis clearly separated the ungrazed sites from the others, while 442 variation within axis two was to some extent greater. Since the treatments with a recently altered 443 grazing regime were grouped with long grazed treatments, eight years of protection from grazing 444 appears not to be a long enough time to alter the composition of spider assemblage at the study 445 site. Furthermore, areas with only a decade of grazing already resembled the long grazed areas in 446 multiple ways.

447 Next to non-existent differences in vegetation between continuously grazed areas and 448 areas with a decade of recovery from grazing were in contrast to our hypothesis emphasizing the 449 importance of the level of grazing. Generally, harsh climatic conditions in northern boreal 450 forests, leading to a slow succession rate and therefore minute detectable changes in vegetation 451 in the time span of only one decade, may explain some of the findings. The study and modelling 
452 by Kumpula et al. (2000) showed that if lichen has been grazed and trampled to extremely low

453 level its recovery is much lower than that of more moderately depleted lichen stand. This might

454 well be the case in our study area as well. Also, changing interspecific competition in the plant

455 community due to changes in microclimate may slow down recovery from grazing (Olofsson

456 2006). Patterns in Thomisidae abundance, however, imply that there might be real differences

457 also between long grazed and intermediate treatments.

460

\section{Conclusion}

462

463 Based on our results, we could not find evidence of the hypothesized increase in spider diversity

464 under intermediate grazing impact by reindeer in lichen dominated dry pine forests in the 465 northern boreal zone, but the hypothesis cannot be rejected based on our data. Our data, of 466 course, comes from only one year and a limited area, and as such is has some limitations.

467 However, it seems rather that instead of being intermediate in relation reindeer impact the 468 treatments where grazing impact had been reversed eight years ago were fairly similar to long 469 term grazed habitats.

470 Focal species, sexes or even life stages can experience the same disturbance in dissimilar

471 ways. However, in sites where one species was highly abundant, the species richness within that

472 family was always lower than the species richness in sites of more even species distribution. This 473 suggests active competitive exclusion. 

same way as to clear-cut forest management in Pajunen et al. (1995), oversimplification of the detrimental effects of heavy grazing on the forest floor spider community should be avoided. The findings only support the existence of substantial habitat quality differences between grazed and ungrazed areas for spiders. Furthermore, it is vital to remember that foraging habits and thus the impact on vegetation also differ between large herbivore grazers (Huntly 1991; Adler et al. 2001). The distinct differences in feeding habits of reindeer between seasons can lead to completely different impacts of the same herbivore species, through winter grazing on ground

482 lichens and summer grazing on grasses and deciduous leaves. Moreover, even though the 483 responses to treatments showed clear family-level habitat preferences among linyphiids and

484 lycosids, certain species within these families showed opposite responses. Thus, 485 oversimplification of family-level habitat preferences should also be avoided. community after heavy grazing, which extends from the lichens even to invertebrates such as spiders. Both of our intermediate treatments with eight years of reindeer exclusion or eight years of grazing were strikingly similar to each other and to the long term grazed treatment. Thus we could not see signs of noticeable recovery from heavy grazing after eight years of protection

491 from grazing, but on the other hand formerly ungrazed habitat was very similar to habitat that 492 had been grazed for decades after eight years of grazing. The recovery of lichen pasture after 493 heavy grazing is a long process (Olofsson 2006; Hansen et al. 2007) and not only for slow494 growing lichens, but also for other vegetation, the physical environment, and for faunistic 495 components like the spiders studied here. 


\section{Acknowledgements}

500 We thank Tanja Kyykkä for her help in spider identification. Tapani Hopkins kindly checked the 501 language.

502

503 References

504 Adler PB, Raff DA, Lauenroth, WK. 2001. The effect of grazing on the spatial

505 heterogeneity of vegetation. Oecologia 128:465-479.

506 Augustine DJ, McNaughton SJ. 1998. Ungulate effects on the functional species

507 composition of plant communities: herbivore selectivity and plant tolerance. The Journal 508 of Wildlife Management 62:1165-1183.

509 Baines D, Sage RB, Baines MM. 1994. The implications of red deer grazing to

510 ground vegetation and invertebrate community structure of Scottish native

511 pinewoods. Journal of Applied Ecology 31:776-783.

512 Bernes C, Bråthen KA, Forbes BC, Hofgaard A, Moen J, Speed JD. 2015. What are the impacts

513 of reindeer/caribou (Rangifer tarandus L.) on arctic and alpine vegetation? A systematic review.

514 Environmental Evidence 4:4.

515 ter Braak CJF, Smilauer P. 1998. CANOCO reference manual and user's guide to

516 Canoco for Windows -software for canonocal community ordination (version

517 4). Microcomputer Power, Ithaca. New York.

518 Bromham LM, Cardillo M, Bennett AF, Elgar MA. 1999. Effects of stock

519 grazing on the ground invertebrate fauna of woodland remnants. Australian Journal of Ecology 
$520 \quad 24: 199-207$.

521 Churchill TB, Arthur JM. 1999. Measuring spider richness: effects of different

522 sampling methods and spatial and temporal scales. Journal of Insect Conservation 3:287-

523295.

524 Colebourn PH 1974. The Influence of Habitat Structure on the Distribution of Araneus

525 diadematus Clerck. Journal of Animal Ecology 43:401-409.

526 Connell JH. 1978. Diversity in Tropical Rain Forests and Coral Reefs. Science 199:1302-1310.

527 Côté SD, Rooney TP, Tremblay J-P, Dussault C, Waller DM. 2004. Ecological impacts of deer

528 overabundance. The Annual Review of Ecology, Evolution, and Systematics 35:113-47.

529 Decalesta DS. 1994. Effect of White-tailed Deer on songbirds within managed forests

530 in Pennsylvania. The Journal of Wildlife Management 41:711-718.

531 Egelkraut D, Kardol P, De Long JR, Olofsson J. 2018. The role of plant-soil feedbacks in

532 stabilizing a reindeer-induced vegetation shift in subarctic tundra. Functional Ecology 32:19595331971.

534 Eskelinen A, Kaarlejärvi E, Olofsson J 2017. Herbivory and nutrient limitation protect warming 535 tundra from lowland species' invasion and diversity loss. Global Change Biology 23:245-255..

536 Evans R. 1996. Some impacts of overgrazing by reindeer in Finnmark, Norway.

537 Rangifer 16:3-19.

538 Frick H, Nentwig W, Kropf C. 2007. Influence of stand-alone trees on epigeic spiders (Araneae)

539 at the alpine timberline. Annales Zoologici Fennici 44:43-57.

540 Foster CN, Barton PS, Lindenmayer DB. 2014. Effects of large native herbivores on other

541 animals. Journal of Applied Ecology 51:929-938. 
542 Foster CN, Barton PS, Wood JT, Lindenmayer DB. 2015. Interactive effects of fire and large

543 herbivores on web-building spiders. Oecologia 179:237-248.

544 Gause GF (1934). Experimental analysis of Vito Volterra's mathematical theory of the struggle

545 for existence. Science 79(2036):16-17.

546 Gotelli NJ, Entsminger GL. 2001. EcoSim: Null models software for ecology.

547 Gotelli NJ, Colwell RK. 2001. Quantifying biodiversity: procedures and pitfalls in the

548 measurement and comparison of species richness. Ecology Letters 4:379-391.

549 Hansen BB, Henriksen S, Aanes R, Saether BE. 2007. Ungulate impact on

550 vegetation in a two-level trophic system. Polar Biology 30:549-558.

551 Hardin G. 1960. The competitive exclusion principle. Science 131(3409):1292-1297.

552 Hartley CL, Macmahon JA 1980. Spider community organization: Seasonal variation and the

553 role of vegetation architecture. Environmental Entomology 9:632-639.

554 Helle T, Kojola I. 1993. Reproduction and mortality of Finnish semi-domesticated

555 reindeer in relation to density and management strategies. Arctic 46:72-77.

556 Helle T, Kajala L, Niva A, Särkelä M. 1998. Poron laidunnuksen vaikutus

557 tunturikoivikoiden rakenteeseen. In: Hyppönen M, Penttinen T,

558 Poikajärvi H (eds.) Poron vaikutus metsä- ja tunturiluontoon.

559 Tutkimusseminaari Hetassa 1997. Metsäntutkimuslaitoksen tiedonantoja. 678:

$560 \quad 132-141$.

561 Huntly N. 1991. Herbivores and the dynamics of communities and ecosystems.

562 The Annual Review of Ecology, Evolution, and Systematics 22:477-503.

563 Jones CG, Lawton JH, Shachak M. 1994. Organisms as ecosystem engineers.

564 Oikos 69:373-386. 
565 Jones CG, Lawton JH, Shachak M. 1997. Positive and negative effects of

566 organisms as physical ecosystem engineers. Ecology 78:1946-1957.

567 Kaarlejärvi E, Eskelinen A, Olofsson J 2017. Herbivores rescue diversity in warming tundra by

568 modulating trait-dependent species losses and gains. Nature Communications 8: 419.

569 Kielland K, Bryant JP, Ruess RW. 1997. Moose herbivory and carbon turnover

570 of early successional stands in interior Alaska. Oikos 80:25-30.

571 Kojola I, Helle T, Aikio P. 1991. Productivity of semi-domesticated reindeer in

572 Finland. Rangifer 11:53-64.

573 Kojola I, Helle T, Niskanen M, Aikio P. 1995. Effects of lichen biomass on

574 winter diet, body mass and reproduction of semi-domesticated reindeer

575 Rangifer tarandus in Finland. Wildlife Biology 1:33-38.

576 Koponen S. 1977. Spider fauna (Araneae) of Kevo area, northenmost Finland. Reports from

577 the Kevo Subarctic Research Station 13:48-62.

578 Koponen S. 1995. Ground-living spiders (Araneae) of old forests in eastern Finland.

579 Memoranda Societatis pro Fauna et Flora Fennica 71:57-62.

580 Koponen S. 1999. Common ground-living spiders in old taiga forests of Finland. Journal of

581 Arachnology 27:201-204.

582 Koponen S. 2002. Ground-living spiders in bogs in northern Europe. Journal of

583 Arachnology 30: 262-267

584 Koponen S. 2004. Effects of intensive fire on the ground-living spider (Araneae) fauna

585 of a pine forest. European Arachnology 2003, Arthropoda Selecta Special Issue

$586 \quad 1: 133-137$. 
587 Koponen S, Koneva GG. 2006. Spiders along a pollution gradient (Araneae). European

588 Arachnology 2005, Acta Zoologica Bulgarica Supplement 1:131-136.

589 Koponen S, Haukioja E, Iso-Iivari L. 1975. Comparison of spider catches and weather in

590 subarctic conditions. Proc 6th Int Arachn Congress, Amsterdam 1974:77-81.

591 Köster E, Köster K, Aurela M, Laurila T, Berninger F, Lohila A, Pumpanen J. 2013. Impact of

592 reindeer herding on vegetation biomass and soil carbon content: a case study from Sodankylä,

593 Finland. Boreal Environmental Research 18:35-42.

594 Köster K, Berninger F, Köster E, Pumpanen J. 2015. Influences of reindeer grazing on above595 and below-ground biomass and soil carbon dynamics. Arctic, Antarctic and Alpine Research $596 \quad 47: 495-503$.

597 Kumpula J, Colpaert A, Kumpula T, Nieminen M. 1997. Suomen

598 poronhoitoalueen talvilaidunvarat [The winter pasture resources of the Finnish

599 reindeer management area]. Kala- ja riistaraportteja, nro 93, Riista ja

600 kalatalouden tutkimuslaitos.

601 Kumpula J, Colpaert A, Nieminen M. 2000. Condition, potential recovery rate, and productivity

602 of lichen (Cladonia spp.) ranges in the Finnish reindeer management area. Arctic 53:152-160.

603 Kumpula J, Fielitz U, Colpaert A. 1999. Porojen laidunten käyttö Pohjois-Lapissa:

604 GPS-seuranta ja satelliitikuvatulkinnat laidunten käytön tutkimisessa [Pasture

605 use of reindeer in northernmost Lapland: GPS-tracking and satellite image

606 data as a study method]. Kala- ja Riistaraportteja nro 150. Riista- ja

607 kalatalouden tutkimuslaitos. 
608 Maliniemi T, Kapfer J, Saccone P, Skog, A, Virtanen R 2018. Long-term vegetation changes of

609 treeless heath communities in northern Fennoscandia: Links to climate change trends and

610 reindeer grazing. Journal of Vegetation Science 29:469-479.

611.

612 Marusik YM, Koponen S. 2002. Diversity of spiders in boreal and arctic zones. Journal of

613 Arachnology 30:205-210.

614 Milchunas DG, Lauenroth WK, Burke IC. 1998. Livestock grazing: animal and

615 plant biodiversity of shortgrass steppe and the relationship to ecosystem

616 function. Oikos 83:63-74.

617 Minoshima M, Takada MB, Agetsuma N, Hiura T. 2013. Sika deer browsing differentially

618 affects web-building spider densities in high and low productivity forest understories. Ecoscience

$61920: 55-64$.

620 Miyashita T, Takada M, Shimazaki A. 2004. Indirect effects of herbivory by deer

621 reduce abundance and species richness of web spiders. Ecoscience 11:74-79.

622 Nilsson SG, Nilsson IN. 1983. Are estimated species turnover rates on islands largely sampling

623 errors? The American Naturalist 595-597.

624 Norris KC. 1999. Quantifying change through time in spider assemblages: sampling

625 methods, indices and sources of error. Journal of Insect Conservation 3:309-325.

626 Oksanen L. 1978. Lichen grounds of Finnmarksvidda, northern Norway, in relation to

627 summer- and winter grazing by reindeer. Reports from Kevo Subarctic Research Station 14:64-

62871.

629 Oksanen L, Moen J, Helle T. 1995. Timberline patterns in northernmost

630 Fennoscandia. Relative importance of climate and grazing. Acta Botanica Fennica 
$631 \quad 153: 93-105$.

632 Olofsson J, Kitti H, Rautiainen P, Stark S, Oksanen L. 2001. Effects of summer

633 grazing by reindeer on composition of vegetation, productivity and nitrogen

634 cycling. Ecography 24:13-24

635 Olofsson J, Stark S, Oksanen L. 2004. Reindeer influence on ecosystem

636 processes in the tundra. Oikos 105:386-396.

637 Olofsson J. 2006. Short- and long-term effects of changes in reindeer grazing pressure

638 on tundra vegetation. Journal of Ecology 94:431-440.

639 Owen-Smith N. 1987. Pleistocene Extinctions: The Pivotal Role of Megaherbivores.

640 Paleobiology 13:351-362.

641 Pajunen T, Haila Y, Halme E, Niemelä J, Punttila P. 1995. Forest fragmentation

642 and ground-dwelling spiders (Arachnida, Araneae) in the southern Finnish

643 taiga. Ecography 18:62-72.

644 Pastor J, Cohen Y. 1997. Herbivores, the functional diversity of plant species, and

645 the cycling of nutrients in ecosystems. Theoretical Population Biology 51:165-179

646 Pastor J, Naiman RJ. 1992. Selective Foraging and Ecosystem Processes in Boreal

647 Forests. American Naturalist 139:690-705.

648 Putman RJ (1994) Effects of grazing and browsing by mammals on woodlands. British Wildlife

$6495: 205-213$.

650 Riechert SE, Tracy CR. 1975. Thermal balance and prey availability: Bases for a

651 model relating web-site characteristics to spider reproductive success. Ecology

$65256: 265-284$. 
653 Samu F, Sunderland KD, Szinetar C. 1999. Scale-dependent dispersal and distribution patterns of 654 spiders in agricultural systems: a review. Journal of Arachnology 27:325-332.

655 Santalahti M, Sund H, Sietiö O-M, Köster K, Berninger F, Laurila T, Pumpanen J, Heinonsalo J. 656 2018. Reindeer grazing alter soil fungal community structure and litter decomposition related 657 enzyme activities in boreal coniferous forests in Finnish Lapland. Applied Soil Ecology 132:7465882.

659 Stark S, Wardle DA, Ohtonen R, Helle T, Yeates GW. 2000. The effect of

660 reindeer grazing on decomposition, mineralization and soil biota in a dry

661 oligotrophic Scots pine forest. Oikos 90:301-310.

662 Stark S, Strömmer R, Tuomi J. 2002. Reindeer grazing and soil microbial processes

663 in two suboceanic and two subcontinental tundra heaths. Oikos 97:69-78.

664 Suominen O. 1999. Mammalian herbivores, vegetation and invertebrate assemblages

665 in boreal forests: feeding selectivity, ecosystem engineering and trophic

666 effects. Annales Universitatis Turkuensis 122.

667 Suominen, O. \& Danell, K. 2006. Effects of large herbivores on other fauna. Large Herbivore

668 Ecology, Ecosystem Dynamics and Conservation (eds K. Danell, R. Bergstrom, P. Duncan \& J.

669 Pastor), pp. 383-412. Cambridge University Press, Cambridge.

670 Suominen O, Niemelä J, Martikainen P, Niemelä P, Kojola I 2003. Impact of reindeer grazing on

671 ground-dwelling Carabidae and Curculionidae assemblages in Lapland. Ecography 26:503-513.

672 Suominen O, Olofsson J. 2000. Impacts of semi-domesticated reindeer on structure

673 of tundra and forest communities in Fennoscandia: a review. Annales Zoologici

674 Fennici 37:233-249. 
675 Suominen O, Persson I-L, Danell K, Bergström R, Pastor J. 2008. Impact of simulated moose

676 densities on abundance and richness of vegetation, herbivorous and predatory arthropods along a

677 productivity gradient. Ecography 31:636-645.

678 Takada M, Baba YG, Yanagi Y, Terada S, Miyashita T. 2008. Contrasting responses of web-

679 building spiders to deer browsing among habitats and feeding guilds. Environmental Entomology $680 \quad 37: 938-946$.

681 Uetz GW. 1991. Habitat structure and spider foraging. In: Bell SA,

682 McCoy ED, Mushinsky HR (Eds.). Habitat Structure: The Physical

683 Arrangement of Objects in Space. Chapman \& Hall, London 325-348.

684 Väre H, Ohtonen R, Mikkola K. 1996. The effect and extent of heavy grazing by

685 reindeer in oligotrophic pine heaths in north eastern Fennoscandia. Ecography

$686 \quad 19: 245-253$.

687 Wardle DA, Barker GM, Yeates GW, Bonner KI, Ghani A. 2001. Impacts of

688 introduced browsing mammals in New Zealand forests on decomposer

689 communities, soil biodiversity and ecosystem properties. Ecological Monographs 71:587-614.

690 Warui CM, Villet MH, Young TP, Jocque R. 2005. Influence of grazing by large

691 mammals on the spider community of a Kenyan Savanna biome. Journal of Arachnology

$692 \quad 33: 269-279$.

693 Ylänne H, Olofsson J, |Oksanen L, Stark S. 2017. Consequences of grazer-induced vegetation

694 transitions on ecosystem carbon storage in the tundra. Functional Ecology 32:1091-1102.

695

696 Figure and Table captions

697 
698 Figure 1. Map of Finland showing the study area.

699

700 Figure 2. The differences between treatments in soil temperature $\left({ }^{\circ} \mathrm{C}\right.$ at the depth of $\left.5 \mathrm{~cm}\right)$, soil

701 moisture (top layer of mineral soil), and total lichen biomass (dry mass g/0.25 $\left.\mathrm{m}^{2}\right)(\mathrm{mean} \pm \mathrm{SD})$.

702 The treatments are Graz - long term grazed area, UGraz - long term ungrazed, NGraz - grazed

703 last 9 years, but previously ungrazed, NUGraz - ungrazed last 9 years, but previously grazed (the

704 number (1) in treatments Graz and UGraz refers to sites that act as a reference to the NGraz

705 treatment and number (2) to those that act as reference to the NUGraz treatment).

706

707 Figure 3. The relationship between lichen biomass (dry mass $\left.\mathrm{g} / 0.25 \mathrm{~m}^{2}\right)$, soil moisture (\% top

708 layer of mineral soil), and soil temperature $\left({ }^{\circ} \mathrm{C}\right.$ at the depth of $\left.5 \mathrm{~cm}\right)$. Statistically significant

709 linear regressions are included into the figures.

710

711 Figure 4. Pooled family level abundances of spider individuals of the three most abundant spider

712 families in different treatments (mean number of individuals per trapping line \pm SD). For the

713 abbreviations of treatments see the legend of figure 2.

714

715 Figure 5. Abundances of spider individuals of four common species between different treatments

716 (mean number of individuals per trapping line \pm SD). For the abbreviations of treatments see the

717 legend of figure 2.

718

719 Figure 6. DCA-ordination visualizing the effect of environmental factors and treatments on

720 spider communities. The symbols for treatments: long term grazed $=\square$, sites where grazing 
721 status changed in $1997=\diamond$, long term ungrazed $=0$. The axes 1 and 2 explained $33.4 \%$ and 16.7

$722 \%$ of the variation (relative eigenvalue portions 0.40 and 0.16 respectively).

723

724 Figure 7. The location of spider species on DCA-ordination axes 1 and 2. Only species with

725 more than $20 \%$ weight on the ordination are shown. The axes 1 and 2 explained $14.5 \%$ and 9.3

$726 \%$ of the variation in the species data (relative eigenvalue portions 0.198 and 0.127 respectively).

727

728 Table 1. List of spider species found in the study.

729

730 Table 2. Twelve most common species and their specimen numbers.

731

732 Table 3. Impact of treatment on response variables (mean and SD, or estimate with $95 \%$

733 confidence limits). Variables that fulfill the assumptions for a parametric test were tested with

734 ANOVA and the F-test $(\mathrm{DF}=5)$. Spider abundances and lichen biomass were tested with the

735 non-parametric Kruskal-Wallis $\chi^{2}$-test $(\mathrm{DF}=5)$. Species richness for pooled families, Lycosidae

736 and Linyphiidae, are rarefied values. Due to the low number of species and specimens, species

737 richnesses of Thomisiidae and Gnaphosidae are absolute values without rarefaction. Site-level

738 richness ( $\alpha$-diversity) is the rarefied number of species per trapping line. $\gamma$-diversity is the

739 rarefied number of species per treatment (with 95\% confidence limit). Bold font indicates

740 variables with statistically significant $(\mathrm{p}<0.05)$ treatment impact. 
742 Table 4. Spearman rank correlations of the abundances (n) and species richnesses (S) of spider

743 families. $(*=\mathrm{p}<0.05, * * \mathrm{p}<0.01)(\mathrm{n}=18)$. Others $\mathrm{n}$ and Others $\mathrm{S}$ mean the abundance and richness

744 respectively of all other spider families than the one tested against.

745

746 Table 5. The responses of spider family species richnesses (s) and abundances (n), as well as the

747 abundances of the most numerous species to environmental variables. Linear regression results

748 are also included $(*=\mathrm{p}<0.05, * * \mathrm{p}<0.01)(\mathrm{df}=16) . \mathrm{S}=$ number of species, $\mathrm{n}=$ number of

749 specimen.

750 
Figure 1

Map of Finland showing the study area. 


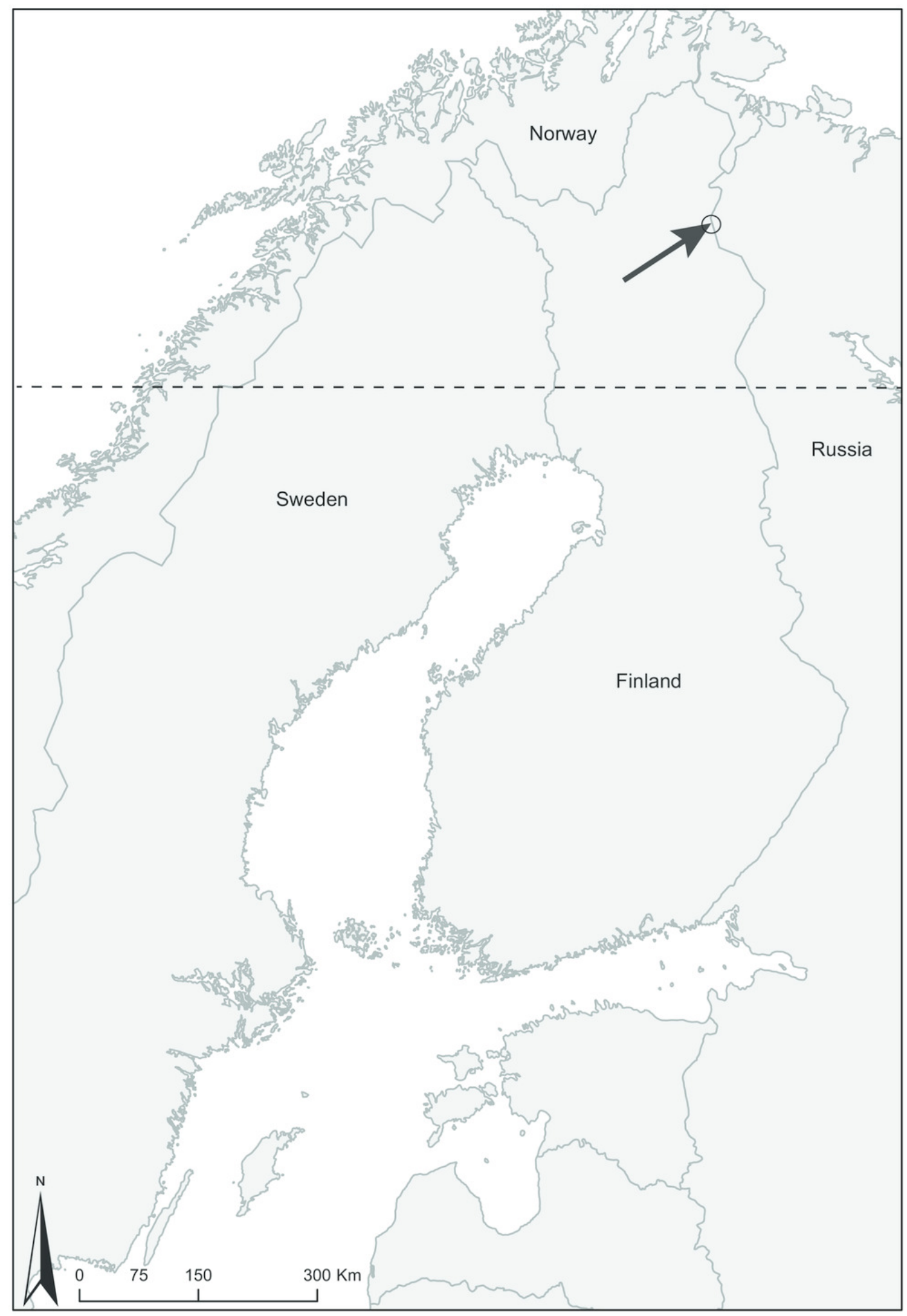




\section{Figure 2}

The differences between treatments in soil temperature $\left({ }^{\circ} \mathrm{C}\right.$ at the depth of $\left.5 \mathrm{~cm}\right)$, soil moisture (top layer of mineral soil), and total lichen biomass (dry mass $\mathrm{g} / 0.25 \mathrm{~m}^{2}$ ) (mean $\pm \mathrm{SD}$ ).

The treatments are Graz - long term grazed area, Ugraz - long term ungrazed, NGraz grazed last 9 years, but previously ungrazed, NUgraz - ungrazed last 9 years, but previously grazed (the number (1) in treatments Graz and Ugraz refers to sites that act as a reference to the NGraz treatment and number (2) to those that act as reference to the NUgraz treatment).

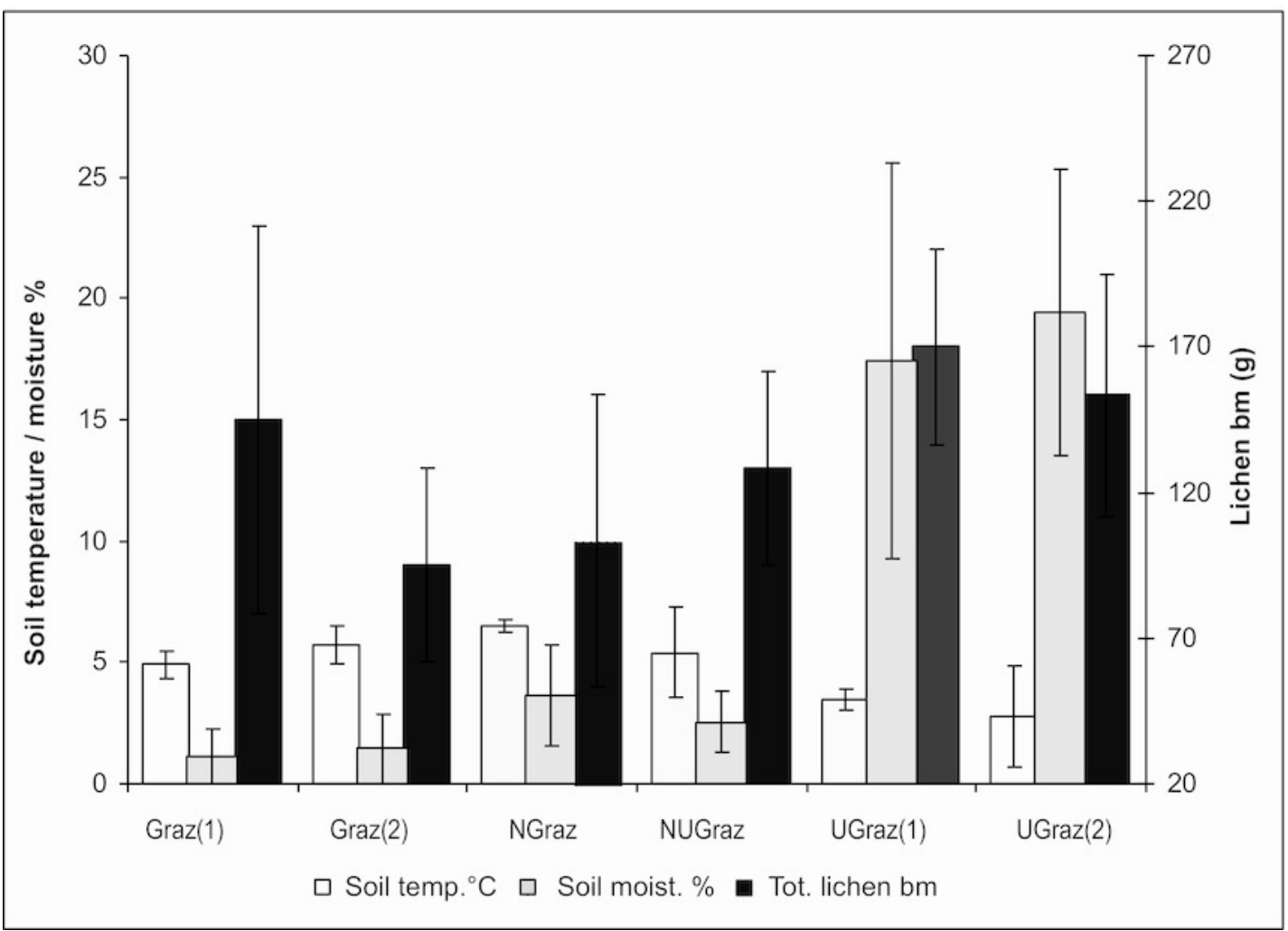


Figure 3

The relationship between lichen biomass (dry mass $\mathrm{g} / 0.25 \mathrm{~m}^{2}$ ), soil moisture (\% top layer of mineral soil), and soil temperature $\left({ }^{\circ} \mathrm{C}\right.$ at the depth of $\left.5 \mathrm{~cm}\right)$.

Statistically significant linear regressions are included into the figures.

A.

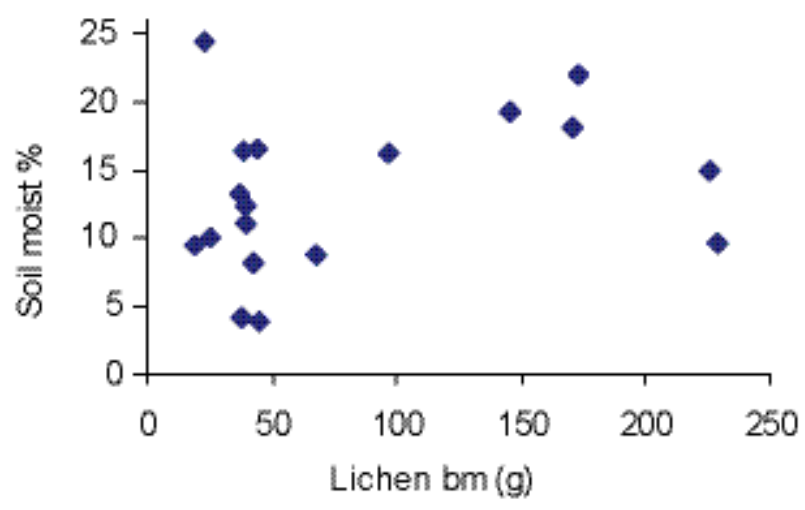

c.

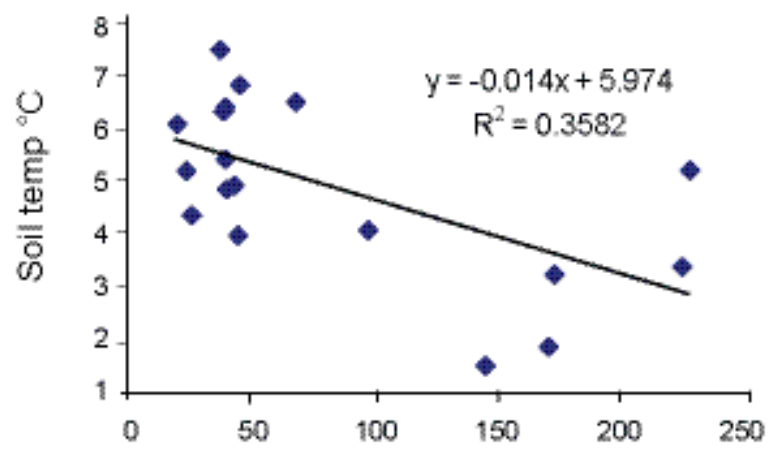

Lichen $\mathrm{bm}(\mathrm{g})$
B.

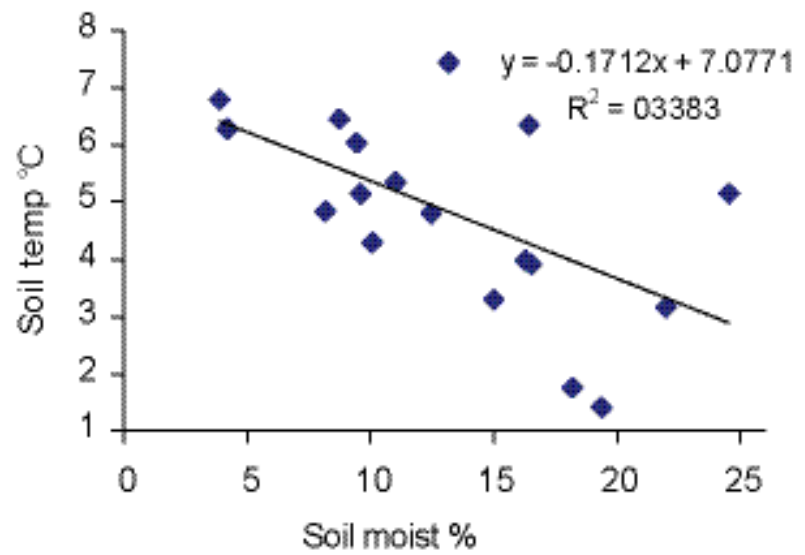


Figure 4

Pooled family level abundances of spider individuals of the three most abundant spider families in different treatments (mean number of individuals per trapping line \pm SD).

For the abbreviations of treatments see the legend of figure 3.

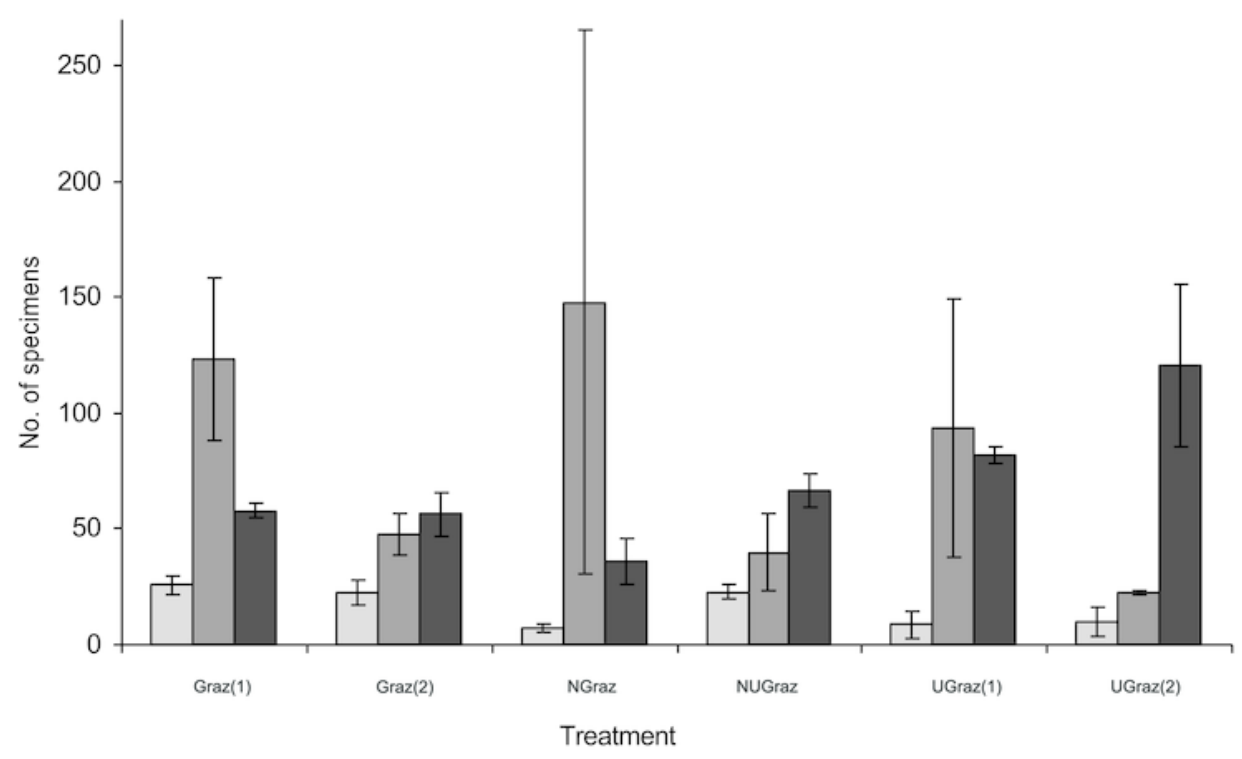

$\square$ Thomisidae $\square$ Lycosidae $\square$ Linyphiidae 
Figure 5

Abundances of spider individuals of four common species between different treatments (mean number of individuals per trapping line \pm SD).

For the abbreviations of treatments see the legend of figure 3. 


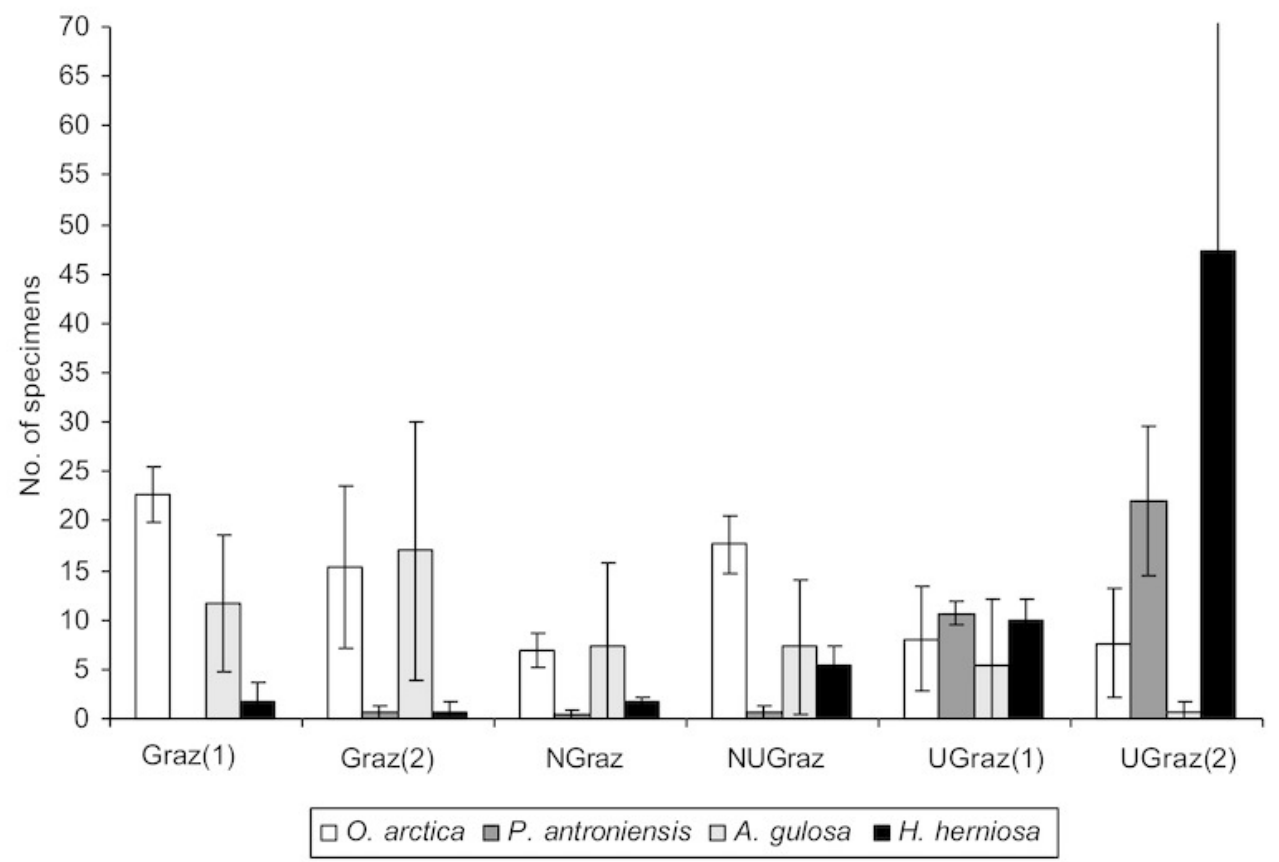


Figure 6

DCA-ordination visualizing the effect of environmental factors and treatments on spider communities.

The symbols for treatments: long term grazed $=\square$, sites where grazing status changed in $1997=\diamond$, long term ungrazed $=0$. The axes 1 and 2 explained $33.4 \%$ and $16.7 \%$ of the variation (relative eigenvalue portions 0.40 and 0.16 respectively).

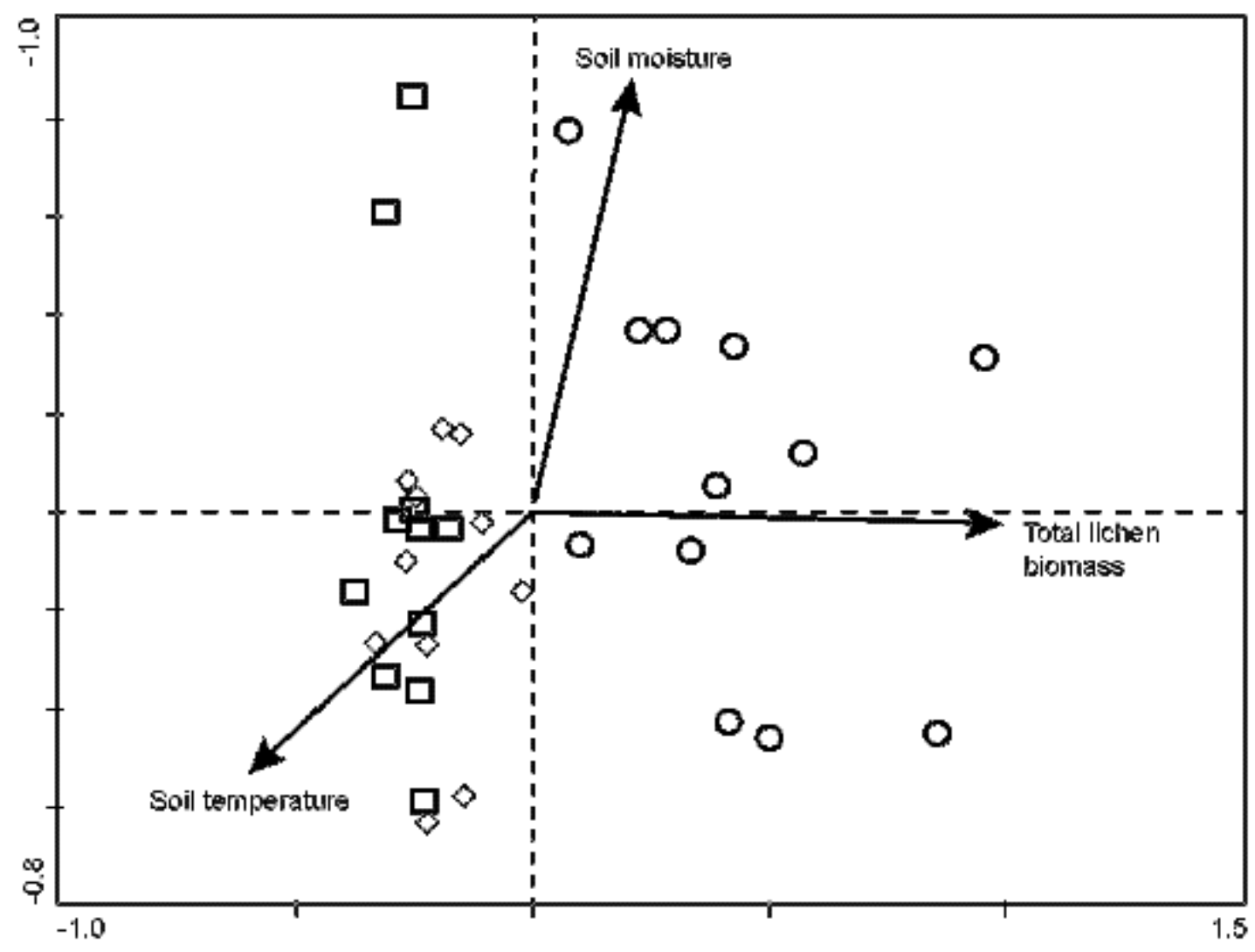


Figure 7

The location of spider species on DCA-ordination axes 1 and 2.

Only species with more than $20 \%$ weight on the ordination are shown. The axes 1 and 2

explained $14.5 \%$ and $9.3 \%$ of the variation in the species data (relative eigenvalue portions

0.198 and 0.127 respectively). 


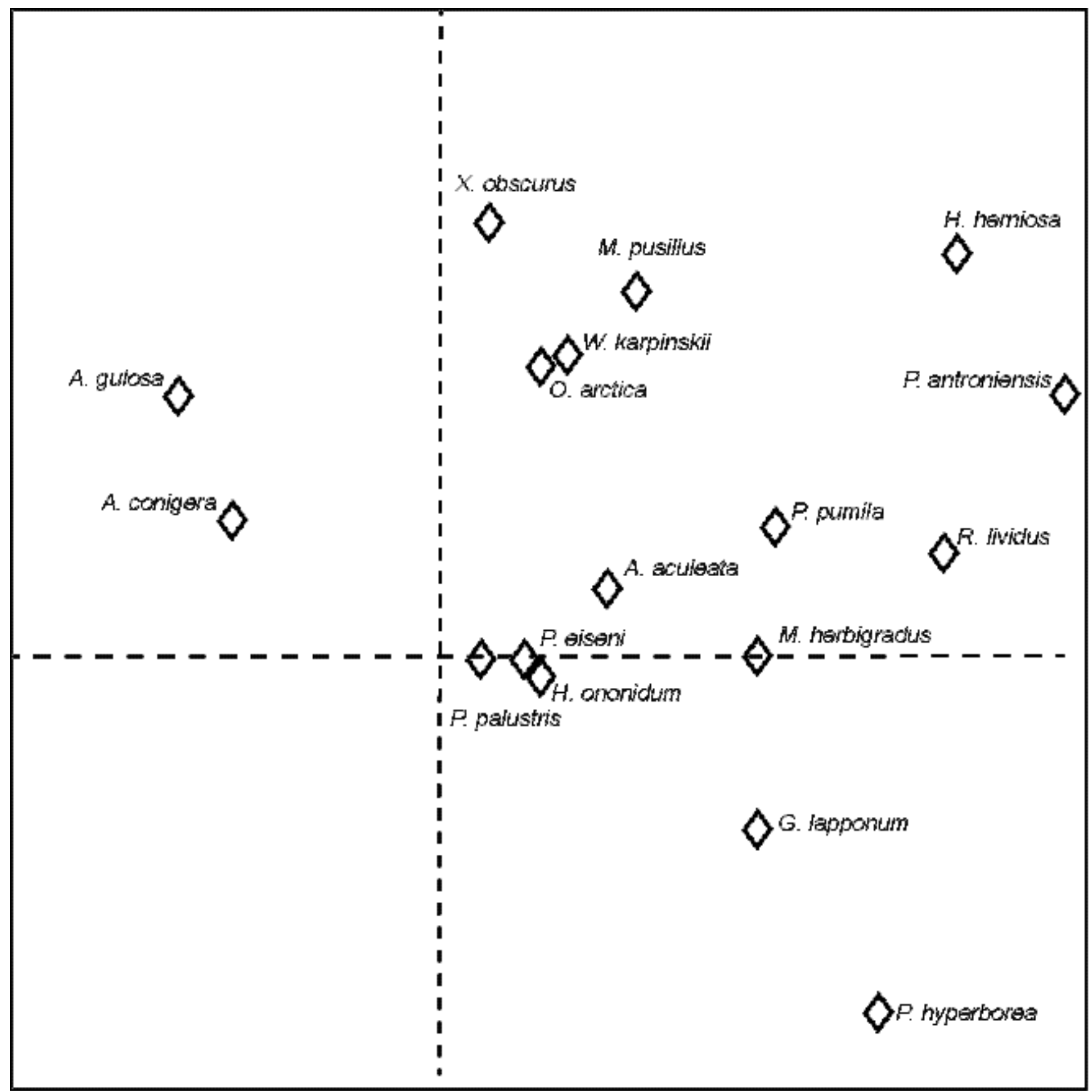




\section{Table $\mathbf{1}$ (on next page)}

List of species found in the study. 
1 Araneidae

2 Hypsosinga albovittata (Westring, 1851)

3 Cercidia prominens (Westring, 1851)

4

5

6

7

8

9

10

11

12

13

14

15

16

17

18

19

20

21

22

23

24

25

26

27

28

29

30

31

32

33

34

35

36

37

38

39

40

41

42

43

44

45

46

\section{Dictynidae}

Hackmania prominula (Tullgren, 1948)

\section{Gnaphosidae}

Gnaphosa lapponum (L. Koch, 1866)

Gnaphosa montana (L. Koch, 1866)

Gnaphosa muscorum (L. Koch, 1866)

Gnaphosa sticta (Kulczynski, 1908

Haplodrassus signifer (C. L. Koch, 1839)

Haplodrassus soerenseni (Strand, 1900)

Micaria alpina (L. Koch, 1872

Zelotes subterraneus (C. L. Koch, 1833)

\section{Hahnidae}

Hahnia ononidum (Simon, 1875)

\section{Linyphiidae}

Agyneta cauta (O. P.-Cambridge, 1902)

Agyneta conigera (O. P.-Cambridge, 1863)

Agyneta gulosa (L. Koch, 1869)

Agyneta subtilis (O. P.-Cambridge, 1863)

Agyneta trifurcata (Hippa \& Oksala, 1985)

Bolepthyphantes index (Thorell, 1856)

Ceratinella brevipes (Westring, 1851)

Centromerus arcanus (O. P.-Cambridge, 1873)

Cnephalocotes obscurus (Blackwall, 1834)

Decipiphantes decipiens (L. Koch, 1879)

Diplocentria bidentata (Emerton, 1882)

Diplocentria rectangulata (Emerton, 1915)

Hilaira herniosa (Thorell, 1875)

Macrargus rufus (Wider, 1834)

Maso sundevalli (Westring, 1851)

Micrargus herbigradus (Blackwall, 1854)

Minyriolus pusillus (Wider, 1834)

Moebelia penicillata (Westring, 1851)

Mughiphantes cornutus (Schenkel, 1927)

Neriene clathrata (Sundevall, 1830)

Oreoneta sinuosa (Tullgren, 1955)

Palliduphantes antroniensis (Schenkel, 1933)

Pocadicnemis pumila (Blackwall, 1841)
47 Porrhomma pallidum (Jackson, 1913)

48 Scandichrestus tenuis (Holm, 1943)

49 Semljicola latus (Holm, 1939)

50 Sisicus apertus (Holm, 1939)

51 Tapinocyba pallens (O. P.-Cambridge,

52 1872)

53 Tenuiphantes alacris (Blackwall, 1853)

54 Tenuiphantes mengei (Kulczynski, 1887)

55 Tenuiphantes tenebricola (Wider, 1834)

56 Tibioploides arcuatus (Tullgren, 1955)

57 Tibioplus diversus (L. Koch, 1879)

58 Walckenaeria antica (Wider, 1834)

59 Walckenaeria capito (Westring, 1861)

60 Walckenaeria cuspidata (Blackwall, 1833)

61 Walckenaeria dysderoides (Wider, 1834)

62 Walckenaeria karpinskii (O. P.-Cambridge,

63 1873)

64 Walckenaeria obtusa (Blackwall, 1836)

65 Walckenaeria unicornis (O. P.-Cambridge,

66 1861)

67 Zornella cultrigera (L. Koch, 1879)

68

69

70

71

72

73

74

75

76

77

78

79

80

81

82

83

84

85

86

87 Evarcha falcata (Clerck, 1757)

88 Neon reticulatus (Blackwall, 1853)

89

90

91 Robertus lividus (Blackwall, 1836

\section{Liocranidae}

Agroeca proxima (O. P.-Cambridge, 1871)

\section{Lycosidae}

Acantholycosa lignaria (Clerck, 1757)

Alopecosa aculeata (Clerck, 1757)

Alopecosa pinetorum (Thorell, 1856)

Pardosa eiseni (Thorell, 1875)

Pardosa hyperborea (Thorell, 1872

Pardosa lasciva (L. Koch, 1879)

Pardosa lugubris (Walckenaer, 1802)

Pardosa palustris (Linnaeus, 1758)

Pardosa sphagnicola (Dahl, 1908)

Philodromidae

Thanatus formicinus (Clerck, 1757)

Salticidae

Therididae 
92 Theonoe minutissima (O. P.-Cambridge,

93 1879)

94

95 Thomisidae

96 Ozyptila arctica (Kulczynski, 1908)

97 Xysticus audax (Schrank, 1803)

98 Xysticus luctuosus (Blackwall, 1836)

99 Xysticus obscurus (Collett, 1877) 
Table 2 (on next page)

Twelve most common species and their specimen numbers. 
1

\begin{tabular}{lllllll}
\hline Species & $\begin{array}{l}\text { Pardosa } \\
\text { eiseni }\end{array}$ & $\begin{array}{l}\text { Alopecosa } \\
\text { aculeata }\end{array}$ & $\begin{array}{l}\text { Pardosa } \\
\text { palustris }\end{array}$ & Ozyptila & Hilaira & Pocadicnemis \\
$\mathrm{n}$ & 622 & 344 & 276 & 235 & herniosa & pumila \\
& & & & & & 159 \\
\hline
\end{tabular}

2

\begin{tabular}{lllllll}
\hline Species & $\begin{array}{l}\text { Agyneta } \\
\text { gulosa }\end{array}$ & $\begin{array}{l}\text { Pardosa } \\
\text { hyperborea }\end{array}$ & Walckenaeria & Palliduphantes & Hahnia & Micrargus \\
$\mathrm{n}$ & 148 & 118 & 117 & antroniensis & ononidum & herbigradus \\
$\mathrm{n}$ & 148 & 103 & 80 & 67 \\
\hline
\end{tabular}

3

4

5 


\section{Table 3 (on next page)}

Impact of treatment on response variables (mean and SD, or estimate with $95 \%$ confidence limits).

Variables that fulfill the assumptions for a parametric test were tested with ANOVA and the Ftest $(D F=5)$. Spider abundances and lichen biomass were tested with the non-parametric Kruskal-Wallis $\chi^{2}$-test $(D F=5)$. Species richness for pooled families, Lycosidae and Linyphiidae, are rarefied values. Due to the low number of species and specimens, species richnesses of Thomisiidae and Gnaphosidae are absolute values without rarefaction. Due to the same reason the Pielou's evenness index J' could not be calculated for Gnaphosidae. Sitelevel richness ( $\alpha$-diversity) is the rarefied number of species per trapping line. $\gamma$-diversity is the rarefied number of species per treatment (with 95\% confidence limit). JK-species no. is the first order jackknife estimate of the total number of species in each treatment (with 95\% confidence limits). Bold font indicates variables with statistically significant $(p<0,05)$ treatment impact. 


\begin{tabular}{|c|c|c|c|c|c|c|c|c|}
\hline & $\begin{array}{l}\text { Mean (SD) } \\
\text { UGraz (1) }\end{array}$ & UGraz (2) & Graz (1) & Graz (2) & NUGraz & NGraz & $\mathrm{F}\left(\chi^{2}\right)$ & $P$ \\
\hline \multicolumn{2}{|l|}{ RICHNES } & & & & & & & \\
\hline$\alpha$ & $26.8(4.1)$ & $28.5(2.3)$ & $23.13(2.1)$ & $27.12(5.9)$ & $28.8(6.0)$ & $21.4(2.8)$ & 1.53 & 0.251 \\
\hline$\gamma$ & $41.5(3.1)$ & $49.3(1.5)$ & $38.7(4.1)$ & $47.0(0.2)$ & $46.0(0.5)$ & $36.9(2.5)$ & - & - \\
\hline Lycosidae & $4.1(0.2)$ & $6.1(0.4)$ & $3.6(0.3)$ & $4.5(0.7)$ & $4.7(1.5)$ & $3.6(0.8)$ & 4.37 & 0.017 \\
\hline Linyphiidae & $11.5(1.4)$ & $9.8(1.4)$ & $11.2(1.7)$ & $10.2(3.1)$ & $11.2(1.7)$ & $12.6(2.0)$ & 0.72 & 0.623 \\
\hline Thomisidae & $1.7(0.6)$ & $2.3(0.6)$ & $2.3(0.6)$ & $3.3(0.6)$ & $2.3(0.6)$ & $1.3(0.6)$ & 4.27 & 0.018 \\
\hline Gnaphosidae & $2.6(0.6)$ & $1.3(0.6)$ & $2.6(0.6)$ & $3.0(1.7)$ & $3.3(1.5)$ & $3.0(1.0)$ & 1.2 & 0.366 \\
\hline \multicolumn{9}{|l|}{ SPIDER } \\
\hline \multicolumn{9}{|l|}{ ABUNDANCE } \\
\hline Total & $203.7(66.0)$ & $166.7(37.3)$ & $225.3(41.4)$ & $135.6(14.2)$ & $144.6(13.7)$ & $206.0(121)$ & $(5.63)$ & 0.344 \\
\hline Lycosidae & $93.3(55.9)$ & $22.3(1.2)$ & $123.3(35.5)$ & $47.7(9.2)$ & $40.0(16.5)$ & $147.7(117.4)$ & (12.09) & 0.034 \\
\hline Linyphiidae & $81.7(3.8)$ & $120.2(35.3)$ & $58.0(3.5)$ & $56.3(9.3)$ & $67(7.2)$ & 35.7 ( 10.0) & $(15.27)$ & 0.009 \\
\hline Thomisidae & $8.7(7.6)$ & $10.0(6.1)$ & $26.0(4.0)$ & $22.3(5.5)$ & $22.7(3.1)$ & $7.3(2.1)$ & $(12.74)$ & 0.026 \\
\hline Gnaphosidae & $9.0(2.6)$ & $2.0(1.0)$ & $6.3(3.5)$ & $4.7(3.1)$ & $6.3(2.5)$ & $7.7(6.7)$ & $(7.45)$ & 0.189 \\
\hline P.antroniensis & $10.7(5.3)$ & $22(7.5)$ & $0(0)$ & $0.7(0.6)$ & $0.7(0.6)$ & $0.3(0.6)$ & 24.41 & $<0.0001$ \\
\hline H. herniosa & $10(2)$ & $47.3(27.1)$ & $1.7(2.1)$ & $0.7(1.2)$ & $5.3(2.1)$ & $1.7(0.6)$ & 7.88 & 0.002 \\
\hline O. arctica & $8(5.3)$ & $7.7(5.5)$ & $22.7(2.9)$ & $15.3(8.1)$ & $17.7(2.9)$ & $7(1.7)$ & 5.24 & 0.009 \\
\hline A. gulosa & $5.3(6.8)$ & $0.7(1.2)$ & $11.7(6.7)$ & $17(13.1)$ & $7.3(6.8)$ & $7.3(8.5)$ & 1.46 & 0.273 \\
\hline \multicolumn{9}{|l|}{ ENV.VAR. } \\
\hline Soil. ${ }^{\circ} \mathrm{C}$ & $3.48(0.45)$ & $2.77(2.07)$ & $4.9(0.56)$ & $5.7(0.80)$ & $5.4(1.84)$ & $6.5(0.24)$ & 4.09 & 0.0212 \\
\hline Moist \% & $0.18(0.04)$ & $0.16(0.05)$ & $0.15(0.08)$ & $0.09(0.04)$ & $0.13(0.04)$ & $0.10(0.06)$ & 1.27 & 0.338 \\
\hline \multicolumn{9}{|l|}{ VEGET.HEIGHT } \\
\hline Lichen & $13.33(1.32)$ & $13.61(0.78)$ & $5.00(1.12)$ & $4.94(1.24)$ & $7.22(0.79)$ & $5.10(0.95)$ & $(43.18)$ & $<0.0001$ \\
\hline Moss & $3.89(2.15)$ & $4.89(1.76)$ & $1.63(0.74)$ & $1.88(0.78)$ & $3.00(1.87)$ & $1.13(0.23)$ & 8.49 & $<0.0001$ \\
\hline Vascular plants & $23.11(8.08)$ & $18.33(3.84)$ & $14.00(2.35)$ & $10.67(3.31)$ & $14.44(4.25)$ & $10.67(2.35)$ & 10.38 & $<0.0001$ \\
\hline \multicolumn{9}{|l|}{ VEGET.BIOM. } \\
\hline Lichen & $165.29(68.14)$ & $181.62(49.12)$ & $29.09(9.84)$ & $31.96(11.96)$ & $41.17(10.50)$ & $50.50(17.27)$ & $(26.65)$ & $<0.0001$ \\
\hline Moss & $8.36(14.28)$ & $11.23(9.52)$ & $4.29(8.46)$ & $8.62(13.75)$ & $21.40(39.24)$ & $2.38(3.15)$ & 0.77 & 0.580 \\
\hline Vascular plants & $43.40(16.39)$ & $35.45(18.82)$ & $28.09(12.11)$ & $36.64(20.37)$ & $34.45(19.20)$ & $23.43(6.94)$ & 1.09 & 0.384 \\
\hline
\end{tabular}




\section{Table 4 (on next page)}

Spearman rank correlations of the abundances ( $n$ ) and species richnesses (S) of spider families. $(*=p<0.05, * * p<0.01)(n=18)$. 


\begin{tabular}{l|cccc} 
& Lycosidae $\mathrm{n}$ & Lycosidae S & Linyphiidae $\mathrm{n}$ & Linyphiidae S \\
\hline Lycosidae $\mathrm{n}$ & 1 & & & \\
Lycosidae S & $\mathbf{- 0 . 8 4 2 * *}$ & 1 & & \\
Linyphiidae n & -0.418 & $\mathbf{0 . 4 9 5 *}$ & 1 & \\
Linyphiidae S & $\mathbf{0 . 7 1 2 * *}$ & $\mathbf{- 0 . 6 2 8 * *}$ & -0.203 & 1 \\
Others n & -0.294 & 0.376 & -0.362 & $\mathbf{0 . 7 1 0 * *}$ \\
Others S & $\mathbf{0 . 5 3 9 *}$ & $\mathbf{- 0 . 6 0 2 * *}$ & 0.221 & -0.005
\end{tabular}




\section{Table 5 (on next page)}

The responses of spider family species richnesses (s) and abundances (n), as well as the abundances of the most numerous species to environmental variables.

Linear regression results are also included $\left(*=p<0.05,{ }^{* *} p<0.01\right)(\mathrm{df}=16) . \mathrm{S}=$ number of species, $\mathrm{n}=$ number of specimen. 


\begin{tabular}{|c|c|c|c|c|c|c|c|}
\hline a) & Lichen bm & $\begin{array}{c}\text { Soil moist. } \\
\%\end{array}$ & $\begin{array}{l}\text { Soil temp. } \\
\quad{ }^{\circ} \mathrm{C} \\
\end{array}$ & b) & Lichen bm & $\begin{array}{c}\text { Soil moist. } \\
\%\end{array}$ & $\begin{array}{l}\text { Soil temp. } \\
\quad{ }^{\circ} \mathrm{C} \\
\end{array}$ \\
\hline & $F$ & $F$ & $F$ & & $F$ & $F$ & $F$ \\
\hline Tot. species (S) & 0,47 & 0,28 & $5,68 *$ & A.aculeata & 1,06 & 0,65 & 1,38 \\
\hline Lycosidae S & 3,64 & 0,33 & $10,71 * *$ & O.arctica & $4,92 *$ & 0,1 & 2,02 \\
\hline Linyphiidae S & 0,41 & 2,31 & 0,02 & $\begin{array}{l}\text { H.ononidum } \\
\text { P.antroniensi }\end{array}$ & 0,26 & 0,69 & 0,05 \\
\hline Thomisidae S & 1,09 & 0,11 & 0,01 & $s$ & $37,17 * *$ & 1,96 & $11,98 * *$ \\
\hline Gnaphosidae S & 2,8 & 0,44 & 1,32 & A. gulosa & $6,28^{*}$ & $4,94 *$ & $6,52 * *$ \\
\hline (n) & 0,43 & 3,32 & 0 & P. pumila & 2,11 & $4,42 *$ & 1,87 \\
\hline Lycosidae $n$ & 0,33 & 0,85 & 1,16 & H.herniosa & $17,7 * *$ & 0,25 & 3,28 \\
\hline Linyphiidae $n$ & $20,69 * *$ & 1,09 & $8,09 *$ & $\begin{array}{l}\text { W.karpinskii } \\
\text { M.herbigrad }\end{array}$ & 0,86 & 0,02 & 0,35 \\
\hline Thomisidae $\mathrm{n}$ & $6,54 * *$ & 0,25 & 2,42 & $u s$ & 0,27 & $12 * *$ & $6,57 * *$ \\
\hline Gnaphosidae $n$ & 0,11 & 3,954 & 0 & & & & \\
\hline
\end{tabular}

